\title{
A Reforma Tributária Nacional
}

FRANCISCO JOSE DE SOUZA

Contador do Ministério da Fazenda

\section{I - DIRETRIZES DA REFORMA}

A

orientação reformista das instituições de base da Administração Pública, que norteia a politica posta em prática pelo Poder Executivo, declaradamente hegemônico na fase atual da organização nacional, propiciou a substituição, a breve prazo, de antigas normas de procedimento governamental, por novos conceitos, praxes e regras operacionais, consentâneas com a estrutura administrativista vigente.

Avulta, dentre essas reformulações, de fundo e de forma, a congruente com 0 nôvo sistema tributário nacional, que radica na Emenda Constitucional $\mathrm{n}^{\circ} 18$, de $1^{\circ}$ de dezembro de 1965 e que se exaure na complementariedade da Lei $n^{\circ} 5.172$, de 25-10-1966.

Exsurge, assim, a construção jurídico-financeira, como um todo orgânico, de caráter nacional, embora frustrando, formalmente e até certo ponto, a esperada codificação tributária.

O ordenamento tributário recém-estabelecido, não obstante as falhas que sua aplicação vai revelar, bem graves, até nos setores estaduais e municipais, é, contudo, um significativo marco na evolução dos institutos jurídicos e econômicos da organização tributária nacional, implantada em um quadro de sistemas gerais de impostos, reais e pessoais, em substituição à partilha da rigidez discriminatória de rendas original, adotada na Carta Constitucional de 1946, fundada no nominalismo dos tributos cumulativamente disfarçados e de exação em cascata.

Por isso, vale repisar, a reforma tributária que se esperava confluísse para o estuário orgânico da codificação, foi, por motivos regimentais, votada no Congresso Nacional como simples lei, que recebeu o n. ${ }^{\circ} 5.172$, com a sanção presidencial, aos 25 de outubro de 1966 e que, consoante a ementa, -

"Dispõe sôbre o Sistema Tributário Nacional e institui normas gerais de direito tributário aplicáveis à União, Estados e Municípios". 
Quando da tramitação do projeto na Comissão Mista do Congresso Nacional, o Senhor Deputado Daniel Faraco, relator da matéria, prestou os esclarecimentos que, por sua importância, vamos, "data venia», reproduzir:

"A necessidade de sistematizar o ordenamento jurídico em matéria financeira constitui, de longa data, uma das preocupações mais sentidas do País».

"Essa tendência obteve, finalmente, expressa consagração constitucional, ao estabelecer a Carta de 1946, em seu art. $5 .^{\circ}$, inciso $\mathrm{XV}$, alinea "b", que compete ao Congresso Nacional legislar sôbre normas gerais de direito financeiro, aplicáveis à União, Estados e Municipios».

Finalmente, em agôsto de 1953, o Ministro Osvaldo Aranha, então titular da Pasta da Fazenda, designou uma comissão integrada pelos Senhores Affonso Almiro, Gerson da Silva, Romeu Gibson, Pedro Teixeira Soares e Rubens Gomes de Souza, êsse último como relator geral, com a especial incumbência de elaborar um projeto de lei de normas gerais de direito financeiro, no campo tributário.

Na Câmara dos Deputados onde recebeu o número 4.834, de 1954, o Projeto foi alvo de minucioso estudo do então Deputado Aliomar Baleeiro, que concluiu por sua aprovação com 54 emendas oferecidas à consideração do plenário.

A partir de então, o projeto não teve mais andamento, embora se possa dizer que sua importância ficou demonstrada, por antecipação, pela influência que passou a exercer sôbre a doutrina, a jurisprudência e, mesmo, a legislação do Pais.

Votada e promulgada, pelo Congresso Nacional, a Emenda Constitucional $\mathrm{n}^{\circ} 18$, que estabeleceu uma completa reorganização do sistema tributário nacional, a Comissão reformulou inteiramente, dentro de nôvo texto básico, o primitivo Projeto.

Em virtude do elevado grau de interdependência da matéria, foram reunidas, em texto único, as leis complementares da Emenda Constitucional n..$^{\circ} 18$ e as normas gerais de direito tributário de que trata o artigo $5^{\circ}$, inciso $\mathrm{XV}$, alinea "b", da Carta de 46 . 
O anteprojeto, inicialmente, divulgado para estudo, foi objeto de amplos debates em todo o Pais, de que resultaram numerosas sugestões, devidamente apreciadas pela comissão na elaboração do texto final entregue ao Govêrno e, posteriormente, encaminhado ao Congresso Nacional pela Mensagem Presidencial $n^{\circ} 14$, acompanhada de Exposição de Motivos n ${ }^{\circ} 604$, do Sr. Ministro da Fazenda.»

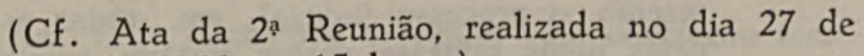
setembro de 1966 , às 15 horas).

O primitivo anteprojeto do Código Tributário Nacional teve sua elaboração a cargo do prof. Rubens Gomes de Souza que, já no ano de 1960 , o dava por concluido. Posteriormente, a Comissão de Reforma do Ministério da Fazenda teve-o como Relator do projeto afinal convertido na Emenda Constitucional $n^{\circ} 18$, de 1965 e da Lei $n^{\circ} 5.172$, de 1966.

$\mathrm{Na}$ apologia do trabalho apresentado à Comissão citada, no primeiro relatório a cargo daquele jurista, assim expõe o chamado "espirito da reforma":

“I/4. ... a Comissão procurou subordinar seus trabalhos a duas premissas que adotou como fundamentais. A primeira delas é a consolidação dos impostos de idênticas naturezas em figuras unitárias, definidas por via de referência às suas bases econômicas, antes que a uma das modalidades juridicas que pudessem revestir. A segunda premissa é a concepção do sistema tributário como integrado no plano econômico e jurídico nacional, em substituição ao critério atual e histórico de origem essencialmente politica, da coexistência de três sistemas tributários autônomos, federal, estadual e e municipal.»

No volume 2, editado pela Fundação Getúlio Vargas, em 1964, dedicado pela Comissão de Reforma do Ministério da Fazenda à divulgação do anteprojeto do Código de Processo Tributário, elaborado pelo jurista Ulhoa Canto, encontramos os seguintes conceitos elucidativos a respeito do trabalho original do professor Rubens Gomes de Souza e que, com a devida vênia, vamos transcrever:

"Quase simultâneamente com a obra acima citada, veio a lume, em edição da Imprensa Nacional, em 1954 , a publicação sob o titulo "Trabalhos da Comissão Especial do Código Tributário Nacional", que inclui, além do projeto que aquela Comissão submeteu ao Executivo 
e êste encaminhou ao Congresso, o anteprojeto de autoria de Rubens Gomes de Souza. Vê-se que, enquanto o projeto se cingiu a inserir algumas normas gerais retoras do processo administrativo tributário (arts. 184 a 190, págs. 73-75), o anteprojeto incorporava, no seu Livro VIII, mais de setenta artigos que regulavam em minúcia o processo tributário administrativo (págs. 343-360), e, no Livio IX, com número de artigos aproximado dos setenta, 0 processo judicial em tôdas as modalidades pelas quais pudesse versar matéria tributária (páginas 360-381), além de incluir, às páginas 381 e seguintes, textos alternativos para a disciplina do processo nas suas duas fases.»

Conseguimente, um sistema tributária é, por assim dizer, a simbiose representativa, a um só tempo, da sintese fiscal da economia e da politica assim como da forma político-social do regime. Por isso, e como já tivemos oportunidade de assinalar, - $\ll \mathrm{Na}$ elaboração dêsses sistemas rígidos muito influi o chamado espirito da época - o «Zeit'geist dos sociólogos alemães». (Cf. As Receitas Derivadas, etc., "in" Boletim da Contadoria Geral da República, págs. 344-346, julho-setembro de 1965).

Impende considerar, também, que a construção jurídica do sistema tributário não se pode dissociar da politica fiscal que é, na concepção de Pajiste, técnica e arte aplicada na realização da atividade financeira do Estado, mas, sobretudo, ciência - "que tem como objetivo realizar a comunicação e equilibrio entre a economia privada e a pública». (Cf. Intr. à Politica Fiscal, página 300$)$.

Ora, como doutrinava Keynes em sua famosa "Teoria Geral» - a impossibilidade do pleno emprêgo e o desequilibrio na distribuição da fortuna e da renda, - terão de ser corrigidos ou atenuados, conquanto distorções inerentes ao regime capitalista, pela ação de uma politica fiscal apolitica, que se caracterize pela humanização ou sensatez de uma pressão tributária razoável ou de eqüidade».

\section{II - COMPOSIÇÃO TRIBUTTARIA}

O sistema que ora se implementa é orgânicamente unificado, de caráter nacional, assentado sôbre um triplice suporte de grupos ou áreas tributáveis, compreendendo as categorias impositivas clássicas: 1) impostos; 2) taxas e 3) contribuições de melhoria, no interior dos quais se opera a partilha da competência tributária e exatorial, entre a União, os Estados e os Municipios, sem esquecer o Distrito Federal das fontes de receitas públicas derivadas da economia privada. 
A constante do poder de tributar é o fato gerador, oriundo da terminologia da Escola Francesa (Le fait générateur) ou o suporte fático, como preferem chamá-lo os financistas alemães. Dentro dessa orientação da ordem geral fiscalista é que se encaixa a definição do impôsto adotada pela Lei $\mathrm{n}^{\circ} 5.172$, de 1966 , tendo por fulcro as linhas mestras dos principios da generalidade, da obrigatoriedade e da ausência de contraprestação específica "verbis":

«Art. 16. Impôsto é o tributo cuja obrigação tem por fato gerador uma situação independente de qualquer atividade estatal específica, relativa ao contribuinte.»

Deixando ao largo, por sua tipologia excepcional, os impostos extraordinários previstos no art. 17 e os empréstimos compulsórios admitidos no artigo $4^{\circ}$, ambos da Emenda Constitucional $n^{\circ} 18$, é plausivel a formulação da sinopse dos impostos, obedecendo-se à classificação por agrupamento ou áreas de incidência fiscal:

$1^{\circ}$ grupo: - Impostos sôbre o Comércio Exterior;
$2^{\circ}$ Impostos sôbre o Patrimônio e a
Renda;
$3^{\circ} \quad$ Impostos sôbre a Produção e a
$4^{\circ} \quad . \quad \begin{aligned} & \text { Circulação, e } \\ & \text { Impostos Especiais. }\end{aligned}$

Vêm, na seqüência natural, as taxas, de significação mais doutrinária do que pròpriamente financeira, como fonte de receita pública, de baixo indice de produtividade, devido ao seu conceptualismo de natureza remuneratória ou comutativa. Com respaldo nessa comutatividade da taxa é que Bielsa a considera mais de natureza administrativa que fiscal, enquanto o prof. Einaudi, como já o havia feito Seligman, deu-lhe a designação de «preço politico».

Por congruente, cabe aqui referir, também, ao critério diferenciador das figuras impositivas, que se estriba, como o faz notar o prof. Bilac Binto (Cfr. - Estudos de Direito Público), nos seguintes postulados:

a) no impôsto não há um beneficio especial para o contribuinte;

b) já a taxa caracteriza-se «por um interêsse público predominante, e um benefício especial mensurável", e

c) enquanto o "preço» é uma receita que não se liga à noção de interêsse público.

Ainda, no tocante às taxas, pode dizer-se com Hugon ( $\mathrm{Ap}$. - O Impôsto), que lhes falta o apanágio da «perfectibilidade, da produtividade e da proficuidade», que o são do impôsto, admitido 
êste na categoria de renda essencial ou principal e aquelas na de secundárias ou acessórias.

Matéria fiscal, como se observa, de conceito assaz controvertido, que muitas vêzes mascara ou dissimula a cobrança de verdadeiros impostos, andou bem o legislador ao evitar o recheio do Estatuto Politico com definições descabidas. Por isso, a Emenda Constitucional n..$^{\circ} 18$, ao referir-se às taxas, no artigo 18 , apenas estipula que -

«Compete à União, aos Estados, ao Distrito Federal e aos Municipios, no âmbito de suas respectivas atribuições, cobrar taxas em função do exercício regular do poder de polícia, ou pela utilização, efetiva ou potencial, de serviços públicos específicos e divisíveis, prestados ao contribuinte ou postos a sua disposição.

Parágrafo único. As taxas não terão base de cálculo idêntica à que corresponda a impôsto referido nesta emenda».

Então, a inteligência do citado artigo 18 autoriza a concluir que as taxas foram secionalizadas em dois grandes grupos, a saber:

19) Taxas do Exercício Regular do Poder de cia, e

$\left.2^{\circ}\right)$ Taxas de Utilização, efetiva ou potencial, de Serviço Público Especial e Divisível.

Relativamente à contribuição de melhoria, ou seja, o "Special assessment» ou "betterment tax", dos norte-americanos, cogita-se, como já tivemos oportunidade de assinalar (Cf. op. cit.) - de um Tributo "sui generis", com atributos peculiares que a diferenciam do impôsto e da taxa. Com efeito, definindo-a, escrevcu Seligman:

"Uma contribuição é o pagamento efetuado de uma só vez, para cobrir o custo de um melhoramento especifico para a propriedade, empreendido no interêsse público e arrecadado pelo Govêrno em proporção ao benefício particular auferido pelo proprietário». (Apud Bilac Pinto, loc. cit.)

A apreciação histórica da introdução do tributo em nosso País já foi objeto de um sucinto estudo nosso (Cfr. loc. cit.) e que, por oportuno, faremos a transcrição:

«Em nosso Pais, a introdução do tributo deve-se a um decreto-lei de 1932, mediante o qual o Govêrno Provisório procurava disciplinar a matéria. Posterior- 
mente, a Constituição de 1934, em seu art. 124, dispôs: "Provada a valorização do imóvel por motivo de obras públicas, a administração que as tiver efetuado poderál cobrar dos beneficiados contribuição de melhoria".

"Já na Constituição de 1946, o legislador, demonstrando maior segurança no trato da matéria, foi muito mais preciso, definindo não só o fato gerador do tributo, como também opôs limite à ação do fisco, proclamando que o ônus provém da valorização imobiliária resultante de serviços públicos (art. 30, I) enquanto o respectivo parágrafo único de modo taxativo declara que:

“A contribuição de melhoria não poderá ser exigida em limites superiores à despesa realizada, nem ao acréscimo de valor que da obra decorrer para o imóvel beneficiado».

«Tècnicamente, isto é, em têrmos de competências conferidas pela Constituição, a contribuição de melhoria não é privativa de determinada Administração, ante as disposições do sobredito artigo 30 , que a partilha com a União, Estados, Distrito Federal e Municípios. Logo, a contribuição de melhoria pertence à classe dos tributos cumulativos, conforme Amilcar de Araújo Falcão (Dir. Trib. Bras., Ric. 1960, pág. 224) ou como ensina o prof. Rubens Gomes de Souza, no rol dos tributos comuns, porque "podem ser criados e cobrados ao mesmo tempo pela União, pelo Estado, pelo Distrito Federal e pelo Municipio (ou Território Federal): quanto a êles não têm aplicação o princípio de bitributação".

"Restava, portanto, que a lei ordinária viesse regulamentar a cobrança do tributo, o que se verificou com a Lei n..$^{\circ} 854$, de 10 de outubro de 1949 - que fixa as normas a serem observadas pela União, Estados e Municípios, para a instituição, lançamento e cobrança da contribuição de melhoria". (loc. cit.).

Para encerrar a apreciação do tributo, convém salientar que a Lei $n .^{\circ} 5.172$, de 1966 , no artigo 82 , seus itens ou incisos, alineas ou letras e parágrafos, não só indica os requisitos minimos a observar, como a publicidade dos atos (memorial ou projeto, orçamento ou custo da obra, parcela a ser financiada pela contribuição) e mais a notificação ao contribuinte do lançamento do tributo, a regulamentação do processo administrativo, correspondente, e, por derradeiro, vem o preceito do

“§ $10^{\circ}$ A contribuição relativa a cada imóvel será determinada pelo rateio da parcela do custo da obra, a 
que se refere a alínea "c" do inciso I, pelos imóveis situados na zona beneficiada, em função dos respectivos fatôres individuais de valorização».

\section{III - TAXEONOMIA IMPOSITIVA}

Aprofundando a análise da classificação dos impostos, por agrupamento ou secionalização, método sociológico de pesquisa, encontraremos os seguintes tipos de gravames ou ônus fiscais.

a) Quanto ao primeiro grupo:

I - Impôsto sôbre a importação, e
II - Impôsto sôbre a exportação.

O primeiro impôsto de competência da União é antigo e, na terminologia fiscal, era chamado de «impôsto aduaneiro» e, no orçamento geral da União, classificava-se como «Impôsto de Importação e Afins», cuja fonte é a primitiva discriminação de rendas da Carta Constitucional de 1946, cujo artigo 15, item I, instituia o. Impôsto sôbre Importação de Procedência Estrangeira. De acôrdo com o artigo 19 da Lei n. ${ }^{\circ} 5.172$, de 1966 ,

"O impôsto, de competência da União, sôbré a importação de produtos estrangeiros, tem como fato gerador a entrada dêstes no território nacional".

Vem, como já se disse, substituir o velho tributo alfandegário de "Direitos de Importação para Consumo", continuando, por isso, regulado pela «Tarifa Aduaneira», mantendo-se a cobrança de acôrdo tom a tríplice forma de cálculo recomendada pelo artigo 22 da pré-citada lei:

$\left.1 .^{\circ}\right)$ aliquota especifica, por determinação legal;

2. ) «ad valorem», e

3. ) o preço de arrematação, em caso de leilão.

Impôsto indireto, a percussão ou incidência sôbre o contribuinte de "jure" ou importador, produz a repercussão ou translação da carga tributária para o contribuinte de fato ou final, que é, por via de regra, o consumidor. O crédito fiscal, porém, é amparado "ex lege», pela configuração do responsável pela satisfação do impôsto, que recai, segundo o artigo 22 , sôbre:

"I - o importador a quem a lei a êle equipar, e II - o arrematante de produtos apreendidos ou abandonados.»

O segundo, agora de competência da União, era, na discriminação de rendas da Constituição Federal de 1946, atribuido aos 
Estados, «ex vi» do artigo $18, \mathrm{~V}$, enquanto a Lei $n .^{\circ} 5.172$, de 1966, assim o configura:

"O impôsto, de competência da União, sôbre a exportação, para o estrangeiro, de produtos nacionais ou nacionalizados, tem como fato gerador a saída dêstes do território nacional".

Marca, porém, o tributo nôvo figurino de politica financeira denominado - «reservas monetárias», postergando o princípio da universalidade orçamentária, no tocante à receita, porque retira do Tesouro Nacional a arrecadação e o contrôle do impôsto.

Haja vista o que estabelece o artigo $1 .^{\circ}$ da Lei Federal número 5.072 , de 12-8-1966, que regula a «cobrança do impôsto de exportação e sua aplicação».

"Art. 19 O impôsto de exportação é de caráter exclusivamente monetário e cambial e tem por finalidade disciplinar os efeitos monetários decorrentes da variação de preços no exterior e preservar as receitas de exportação".

Ainda, a referida lei dispõe que a arrecadação do impôsto de exportação, recolhida ao Banco do Brasil S. A., será escriturada em conta especial a crédito do Banco Central da República do Brasil, que, por sua vez, «manterá, em sua contabilidade, registro destacado para as operações relacionadas com o impôsto de exportação, as quais serão incluidas na prestação de contas que aquela entidade fizer ao Tribunal de Contas da União", de acôrdo com o preceito do artigo $7 .^{\circ}$.

Tendo sido excluido da «Receita Tributária» da proposta orçamentária para o exercício de 1967, aliás já convertida em lei de meios, a arrecadação do impôsto de exportação, nos precisos têrmos do artigo $50^{\circ}$ da Lei $5.072 / 66$,

“... servirá para a constituição de reservas monetárias e terá aplicação específica, de conformidade com a programação que fôr aprovada pelo Conselho Monetário Nacional, com a seguinte destinação:

a) reforçar os recursos do Fundo de Estábilização da Receita Cambial, de que trata o Decreto n ${ }^{\circ} 57.383$, de 3 de dezembro de 1965, que regulamentou a Lei n. ${ }^{\circ} 4.770$, de 15 de setembro de 1965 .

b) servir de recurso para reparar as variações acidentais no mercado cambial».

b) Quanto ao segundo grupo:

I - Impôsto sôbre a propriedade territorial rural; 
rial urbana;

II - Impôsto sôbre a propriedade predial e territo-

III - Impôsto sôbre a transmissão de bens imóveis e de direitos a êles relativos, e natureza.

IV - Impôsto sôbre a renda e proventos de qualquer

O impôsto do item I, acima, na "distributing clause". original da Carta Politica de 1946, era da competência dos Estados, "ut" artigo 19, I - «propriedade territorial, exceto a urbana», pois que a matéria tributável da ressalva cabia aos Municipios. Com a Emenda Constitucional n. ${ }^{\circ} 10$, de 9 de novembro de 1964, foi acrescentado ao artigo 15 da Constituição Federal de 1946 mais um item, o VI, por meio do qual foi conferida à União a competência para tributar a propriedade territorial rural.

Tal aditivo tornou possivel ao Congresso Nacional legislar sôbre «Estatuto da Terra», Lei de inequivoco alcance sócio-econômico, que recebeu o . $^{\circ} 4.504$, ao ser sancionada pelo Presidente da República, em 30 de novembro de 1964, e que vem a ser o principal instrumento para concretizar-se a Reforma Agrária.

Quanto ao tributo, a Lei $n^{\circ} 5.172$, de 1966 , em seú artigo 29 estatui que -

"O Impôsto, de competência da União, sôbre a propriedade territorial rural, tem como fato gerador a propriedade, o dominio útil ou a posse de imóvel por natureza, como definido na lei civil, localizado fora da zona urbana do municipio».

Já a tributação do item Ii, "sôbre a propriedade predial e territorial urbana", constitui a tradicional fonte de receita fiscal dos municípios, com o antigo nome de impôsto de décima, talvez somente superado, na ordem da produtividade, pelo extinto «im pôsto de indústrias e profissões».

O terceiro - "Impôsto sôbre a transmissão de bens imóveis e de direitos a êles relativos» - cabe aos Estados e incide na trans missão "in genere". ou seja, na transmissão da propriedade ou de direitos "inter vivos" e "mortis causa", compreendida assim a transmissão "jura in re aliena", excetuados os direitos reais de garantia, como o penhor, a anticrese e a hipoteca, mais incidindo também sôbre a cessão daqueles mesmos direitos reais.

O seguinte, que é o quarto e último do grupo "b", - é o "Impôsto sôbre a renda e proventos de qualquer natureza" — de competência da União e o mais produtivo, em têrmos de rentabilidade, dos chamados impostos diretos e pessoais, assim compreendidas as pessoas naturais ou físicas $e$ as juridicas, e ainda o 
«de cujus», nos casos de espólio. Como impôsto direto, à cobrança precede o estăgio do assento ou lançamento, com base na declaração do contribuinte, ou, então, pelo desconto na fonte e nos casos previstos na lei fiscal.

Impôsto que goza de ampla simpatia entre governantes e financistas, já se chegou a dizer que, pela tributação da renda, se poderia chegar a uma repartição da renda social mais justa ou, então, corrigir a desigualdade na distribuição. O postulado liga-se à conceituação de Adolfo Wagner, citada por Hugh Dalton (Cf. Finanças Públicas, pág. 115), de que

"O economista alemão Wagner merece o crédito de ter sido um dos primeiros a insistirem em que a tributação deveria ser usada para reduzir a desigualdade de rendas. Sua chamada opinião «sócio-política» de finanças públicas ainda desagrada a grandes autoridades no assunto mas, em princípio, é sólida e está sendo cada vez mais adotada na prática moderna, já que uma distribuição menos desigual será tão desejável quanto uma produção mais de riquezas".

Conceituando o tribute, o artigo 43 da Lei n. $.^{\circ} 5.172 / 66$ o faz, como sempre, pela «causa eficiente», ao estabelecer que -«tem como fato gerador a aquisição da disponibilidade econônica ou jurídica»:

I -- de renda, assim entendido o produto do capital, do trabalho ou da combinação de ambos;

II - de proventos de qualquer natureza, assim entendidos os acréscimos patrimoniais não compreendidos no inciso anterior.

A mecânica do impôsto não é, porém, de fácil compreensão, quer em se tratando do preparo da declaração de rendimentos e respectivos cálculos, mais a comprovação, quer pela destinação ou distribuição cin produto arrecadado pela União, nos Estados e Municipios.

Com efeito, no que respeita à partilha da arrecadação, mister é que se recorra à Lei n." 5.172 , de 1966, que, regulamentando a reforma tributária oriunda da Emenda Constitucional n..$^{\circ} 18$, de 1965 , estabeleceu normas gerais, quer de ordem legislativa, quer tributária e, ainda, normas complementares aplicáveis à legislação tributária.

Eis que, de conformidade com o artigo 83 daquele diploma normativo, os Estados e Municípios poderão participar de até $10 \%$ (dez por cento) do "quantum" arrecadado na respectiva jurisdição exatorial, do impôsto incidente sôbre o rendimento das pessoas 
fisicas, bem como do impôsto sôbre produtos industrializados exceto o cobrado sôbre íumc's e bebidas alcoólicas .

c) Impostos sôbre a Produção e a Circulação.

Neste grupo, situam-se os impostos que, por sua natureza, ou seja, incidentes sôbre mercadorias, «lato sensu», são fatôres de variação do custo de vida, pela majoração do preço de venda, segundo a rigidez, a sensibilidade ou elasticidade, quer da oferta, quer $d:$ demanda efetiva, a menos que se verifiquem os efeitos de substituição por artigos similares ou sucedâneos.

Por primeiro, vem o impôsto sôbre produtos industrializados, em substituição ao antigo "impôsto de consumo". Tributo indireto, em sua tributação opera-se o fenômeno fiscal da translação ou repercussão, pela transferência da carga fiscal do contribuinte legal ou "de jure", para o consumidor que é, assim, o contribuinte de fato ou final.

Contudo, é a viga mestra da receita tributária da União, e sua produtividade é permanente, sobrepujando a do impôsto de renda. Recentemente o Poder Público editou o Decreto-lei n. ${ }^{\circ} 34$, de 18-11-1966, dispondo sôkre a nova denominação (Impôsto sôbre Produtos Industrializados) do antigo Impôsto de Consumo, regido pela Lei n. ${ }^{\circ} 4.502$, de 30-11-1964.

Como traços marcanies e diferenciadores do impôsto, a lei declara-o de natureza seletiva, com base na essencialidade dos produtos (art. 48) e de indole não-cumulativa (art. 49).

Em seguimento, vem o novel e já famoso - "Impôsto Estadual sôbre Operações Relativas à Circulação de Mercadorias" - que, além de servir de pasto para discussões e controvérsias sôbre questões de aliquota e de incidência, e das repercussões negativas para as finanças dos Estados e Municípios, vem sendo responsabilizado pelo atual surto de encarecimento do custo dos gêneros marcados pela demanda rígida ou inelástica, provocando a alta mais que proporcional dos preços de venda ao consumidor, reduzindo ainda mais a débil capacidade aquisitiva ou poder de compra dos econômicamerte menos favorecidos.

Atribuído aos Estados, em substituição ao antigo «Impôsto sôbre Vendas e Consignações», a incidência passou a ser na circulação e não mais nas vendas ou consignações, e tem a seu favor a unicidade exatorjal, enquanto aquêle era de natureza cumulativa e de cobrança $\mathrm{cm}$ cascata. No primeiro relatório da Comissão elaboradora do anteprojeto da reforma tributária, a cargo do professor Rubens Gomes de Souza, encontra-se o pronunciamento sôbre o impôsto em foco, que "data venia", vamos transcrevê-lo, textualmente:

"3/38. Essa nova estruturação começa, de acôrdo com uma das diretrizes básicas do sistema projetado, por 
desvincular o impôsto dos negócios jurídicos especificos de compra e venda ou de consignação. Em lugar de referir essas duas modalidades, atribui-se ao impôsto incidência genérica sôbre as operações relativas à circulação de mercadorias, qualificada, porém, às realizadas por comerciantes, industriais e produtores, de modo a preservar a natureza mercantil do tributo, de resto já indicada pela identificação da circulação como sendo a de mercadorias".

(Cfr. Pág. 48 do volume - 17 - Reforma Tributária Nacional, editado pela Fundação Getúlio Vargas).

Ainda sôbre o assunto, permitimo-nos enriquecer êste despretensioso escólio com as distinções fixadas pelos professôres Arnold Wald e Gugo Sigelmann, quanto ao antigo impôsto (Vendas e Consignações) e o atual (sôbre a Circulação de Mercadorias):

"As diferenças básicas entre as duas tributações se referem ao fato gerador e ao modo de cálculo do impôsto. $\mathrm{O}$ impôsto de vendas e consignações incidia sôbre um ato jurídico bilateral - a venda mercantil - enquanto o impôsto de circulação é cobrado, em tese, sôbre um simples fato material - a saída da mercadoria do estabelecimento comercial, industrial ou produtor". (Cfr. Artigo "in" Correio da Manhã, Rio, 20 de janeiro de 1967, página 9).

$\mathrm{O}$ artigo 12 e seus parágrafos $1 .^{\circ}$ e $2 .^{\circ}$, que instituiram e caracterizaram o impôsto, fornecem-nos, em suma, as seguintes normas retoras:

a) atribuido à competência tributária dos Estados incidindo nas operações circulatórias de mercadorias, é também deferido o direito de cobrança aos Municipios, em proporção não superior a $30 \%$ da aliquota fixada pelo Estado;

b) unicidade de aliquota para tôdas as mercadorias, cabendo ao Senado Federal fixar limite, mediante resolução e em consonância com a lei complementar:

c) tributo de indole não-cumulativa, implica no abatimento do montante cobrado anteriormente, em cada nova operação;

d) os gêneros de primeira necessidade estão livres da incidência do tributo, e

e) a cobrança concedida aos Municípios é restrita às operações ocorridas nos respectivos territórios, «mas independente da efetiva arrecadação pelo Estado». 
Com a Lei Federal n. ${ }^{\circ} 5.172$, de 1966 , o tributo foi melhor regulado. De acôrdo com o artigo 52 , o fato gerador da obrigação fiscal é a saída de mercadorias "de estabelecimento comercial, industrial ou produtor". Pelo artigo 58 - "Contribuinte do impôsto é o comerciante, industrial ou produtor que promova a saida da mercadoria». A Lei n..$^{\circ} 1.165$, de 13-12-1966, do Estado da Guanabara, deu ampla regulamentação ao impôsto, em mais de 70 artigos.

O seguinte é o «Impôsto sôbre Operações de crédito, câmbio e seguro, e sôbre operações relativas a titulos e valôres mobiliários», que veio substituir o antigo "impôsto do sêlo". Ante a extensão do título do impôsto, talvez seja mais fácil compreendê-lo pela classificação das áreas de incidência, segundo o esquema infra:

\section{I - Impôsto sôbre operações de crédito, câmbio, seguro e capitalizaçãó, e \\ II - Impôsto sôbre operações relativas a títulos e valôres mobiliários.}

Prosseguindo no critério definidor pelo crivo do chamado suporte fático, Lei n..$^{\circ}$ 5.172, de 1966, estabelece:

"Art. 63. O impôsto, de competência da União, sôbre operações de crédito, câmbio e seguro, e sôbre operações relativas a títulos e valôres mobiliários, tem como fato gerador:

I - quanto às operações de crédito, a sua efetivação pela entrega total ou parcial do montante ou do valor que constitua o objeto da obrigação, ou sua colocação à disposição do interessado;

II - quanto às operações de câmbio, a sua efetivação pela entrega de moeda nacional ou estrangeira, ou de documento que a represente, ou sua colocação à disposição do interessado, em montante equivalente à moeda estrangeira ou nacional entregue ou posta à disposição por êste;

III - quanto às operações de seguro, a sua efetivação pela emissão da apólice ou do documento equivalente, ou recebimento do prêmio, na forma da lei aplicável;

IV - quanto às operações relativas a títulos e valôres mobiliários, a emissão, transmissão, pagamento ou resgate dêstes, na forma da lei aplicável".

A Lei Federal n. ${ }^{\circ} 5.143$, de 20-10-1966, deu ao gravame fiscal o «nomen juris» de - «Impôsto sôbre Operações Financeiras» e outorga ao Banco Central da República a fiscalização da aplicação da lei predita, que, em razão dêsse encargo, o beneficiou com um determinado percentual, a saber: 
«Art. 11. Do produto da arrecadação do impôsto, será destacada uma parcela, não superior a $2 \%$ (dois por cento), destinada às despesas de custeio do Banco Central da República do Brasil na substituição da taxa de fiscalização referida no $\S 10^{\circ}$ do artigo 16 da Lei n. ${ }^{\circ} 4.595$, de 31 de dezembro de 1964, que fica extinta».

Traço singular dêste impôsto, e por isso digno de realce, é a destinação do produto arrecadado para formar reservas monetárias, segundio a forma estabelecida na lei:

"Art. 12. Deduzida a parcela de que trata o artigo anterior, a receita liquida do impôsto se destinará à formação de reservas monetárias, as quais serão aplicadas, pelo Banco Central da República do Brasil, na intervenção dos mercados de câmbio e de títulos, na assistência a instituições financeiras, particularmente ao Banco Nacional do Desenvolvimento Econômico e em outros fins, conforme estabelecer o Conselho Monetário Nacional".

Êste, como o de exportação, é o segundo impôsto que, fugindo à disciplina do clássico principio orçamentário da universalidade, deixou de integrar a receita tributária do Orçamento Geral da União, para o vigente exercício de 1967 , a que se refere a Lei n. ${ }^{\circ} 5.189$, de 8-12-1966.

Em seguimento vem o - "Impôsto sôbre serviços de transportes e comunicações" - também atribuido àl União e, segundo a praxe adotada pela Lei n. $0^{\circ} 5.172-66$, é definido pelo fato gerador, nos itens I e II, do artigo 68, "verbis":

"I - a prestação do serviço de transporte, por qualquer via, de pessoas, bens, mercadorias ou valôres, salvo quando o trajeto se contenha inteiramente no território de um mesmo município;

II - a prestação do serviço de comunicação, assim entendendo a transmissão e o recebimento, por qualquer processo, de mensagens escritas, faladas ou visuais, salvo quando os pontos de transmissão e de recebimento se situem no território de um mesmo município e a mensagem em curso não possa ser captada fora dêsse território".

Fechando o terceiro grupamento, aparece o- "Impôsto sôbre serviços de qualquer natureza" - destinado aos Municípios, e incidente, consoante o artigo 71 ,

"... sôbre serviços de qualquer natureza, tem como fato gerador a prestação, por emprêsa ou profissional autônomo, com ou sem estabelecimento fixo, de serviço que não configure, por si só, fato gerador de impôsto de competência da União ou dos Estados". 
Esclarecendo o alcance do tributo, assim se expressa o Primeiro Relatório da Comissão de Reforma Tributária, a cargo do prof. Rubens Gomes de Souza:

$\ll 3 / 16$. O art. 16 da Emenda «B» atribui aos Municípios um impôsto sôbre serviços de qualquer natureza, exceto aquêles cuja tributação foi reservada à União pelo inciso III do artigo anterior».

A sua vez, a Lei n. ${ }^{\circ} 1.165$, de 13-12-1966, do Estado da Guanabara, traça o seguinte perfil da imposição fiscal:

“Art. 74. A obrigação de pagar o impôsto sôbre serviços nasce ao ter lugar a prestação de serviços de qualquer natureza, por pessoa juridica ou profissional autônomo, com objetivo de lucro ou remuneração".

Vem, assim, a modo de substituição do extinto «Impôsto de Indústrias e Profissões», e formava com o predial as duas mais importantes arrecadações de receitas municipais. Tratava-se de um impôsto acoimado de ilegalidade porque tributava, disfarçadamente, a renda, dando azo à impetração de sucessivos mandados de segurariça, pelos que o não admitiam. Depois, a cobrança era biforme; havia a parte fixa cobrada pelos Municipios, diretamente ao contribuinte, e a variável, a mais produtiva, pelos Estadós, como adicional do Impôsto de "Vendas e Consignações" bastando essa particularidade para se avaliar a situação financeiramente desvantajosa para as municipalidades.

d) Impostos Especiais.

O «Impôsto sôbre operações relativas a combustiveis, lubrificantes, energia elétrica e minerais do País», na conformidade do preceito do artigo 74 , da Lei $n .^{\circ} 5.172$, de 1966 , compete à União e tem por fato gerador:

$$
\begin{aligned}
& \text { I - a produção; } \\
& \text { II - a importação; } \\
& \text { III - a circulação; } \\
& \text { IV - a distribuição, e } \\
& \text { V - o consumo, «assim entendida a venda do } \\
& \quad \text { produto ao público». }
\end{aligned}
$$

Disciplinando a incidência, o parágrafo $2 .^{\circ}$ daquele artigo estabelece:

"O impôsto incide, uma só vez, sôbre uma das operações previstas em cada inciso dêste artigo como dispuser a lei; e exclui quaisquer outros tributos, sejam quais forem sua natureza ou competência, incidentes sôbre aquelas operações». 
Por seu conteúdo esclarecedor, vale a transcrição dos seguintes itens do Relatório já aludido:

«3/51. O art. 17 da Emenda «B» mantém, na competência federal, a tributação única relativamente a combustiveis, lubrificantes, energia elétrica e minérios de que tratam o inciso III do art. 15 da Constituição e o seu $\S 2 .^{\circ}$. Este é o primeiro dos «impostos especiais» a que se refere o art. $7 .^{\circ}$ da Emenda, assim designados por trancenderem a competência reservada a cada um dos governos (como neste caso), ou em razão do seu caráter extraordinário (como no caso do art. 18)».

Come se recorda, a discriminação original do artigo 15 da Lei Superior, federal, de 1946, era de indole enumerativa quanto à competência da União para decretar impostos, dentre êsses o incidente sôbre a área impositiva do inciso III:

"produção, comércio, distribuição e consumo, e bem assim importação e exportação de lubrificantes e de combustiveis liquidos ou gasosos de qualquer origem ou natureza, estendendo-se êsse regime, no que fôr aplicável, aos minerais do País e à energia elétrica".

E, prestes, vinham as normas tributárias, financeiras e partitivas do parágrafo $2 .^{\circ}$, "verbatim":

“A tributação de que trata o n. . III terá a forma de impôsto único, que incidirá sôbre cada espécie de produto. Da renda resultante, sessenta por cento, no mínimo, serão entregues aos Estados, ao Distrito Federal e aos Municípios, proporcionalmente à sua superfície, população, consumo e produção, nos têrmos e para os fins estabelecidos em lei federal».

e) Impostos extraordinários

Nesta ordem expositiva, pode-se, ainda, aludir a um quinto grupo de impostos - os extraordinários - se bem que referidos na Emenda Constitucional n. ${ }^{\circ} 18$, de 1965, na Seção V, artigo 17, na categoria dos impostos especiais.

A Lei n. ${ }^{\circ}$ 5.172, de 1966, deu, ao nosso ver, melhor redação, romo seja:

"Art. 76. Na iminência ou no caso de guerra externa, a União pode instituir, temporàriamente, impostos extraordinários compreendidos ou não entre os referidos nesta lei, suprimidos, gradativamente no prazo máximo de 5 (cinco) anos, contados da celebração da paz». 
Em verdade, a autorização já constava do texto primitivo da Lei Matriz de 1946 , considerando que o preceito do parágrafo $6 .^{\circ}$ do artigo 15 é, "mutatis mutandis", o do artigo 76 da Lei número 5.172, de 1966, supra transcrito.

Recorrendo, como já o fizemos nesta tentativa de interpretação e exposição da Reforma Tributária, ao relatório a cargo do mestre Rubens Gomes de Souza, vamos reproduzir a exegese:

“3/57. O art. 18. da Emenda "B", relativo aos impostos extraordinários de guerra, corresponde à atual $\S 80^{\circ}$ do art. 15 da Constituição. Esste artigo admite, nas condições nêle previstas, a criação de impostos de qualquer natureza, por exceção, ressalvada, aliás no art. $7 .^{\circ}$, à norma básica de que os impostos componentes do sistema tributário nacional são exclusivamente os enumerados nos arts. 9. a 17 da Emenda».

"Dentro do mesmo espírito, êsse artigo permite à União criar, temporàriamente, impostos que normalmente competem aos Estados ou aos Municipios naturalmente sem prejuizo de que êstes continuem a exercer a sua própria competência a respeito de tais impostos". ( $\mathrm{Cf}$. Vol. cit., pág. 52).

\section{IV - DISTRIBUIÇAOO DE RECEITAS TRIBUTÁRIAS DA UNIÃO}

Apercebido do caráter unificador que presidiu à elaboração da reforma tributária em tela, ao legislador não escaparam as perspectivas sombrias reservadas às já de si precárias finanças estaduais e municipais, ante o impacto das novas disposições tributárias implantadas e vigorantes com o início dêste exercício de 1967.

Daí, certamente, a consignação, na Emenda Constitucional n. ${ }^{\circ} 18$, de certos principios gerais distributivos de receitas da União aos Estados e Municipios, estabelecidos nos artigos 20 "usque" 24.

Sobrevindo a lei complementar da reforma tributária, número 5.172 , de 1966 , nela a matéria recebeu melhor disciplina, no Título VI do Livro Primeiro, Capítulos I a IV, artigøs 83 a 95, declarando-se, nas "Disposições Gerais», que:

I - mediante convênio com a União, os Estados e Municípios poderão participar de até $10 \%$ (dez por cento) da arrecadação efetuada nos respectivos territórios:

a) do impôsto sôbre rendimentos de pessoas físicas (art. 43), e

b) do impôsto sôbre produtos industrializados (artigo 46), "excluído o incidente sôbre o fumo e bebidas alcoólicas".

II - o convênio regulará o processo distributivo; 
III - a lei federal poderá atribuir aos Estados e Municipios a arrecadação de impostos da Unnião, "cujo produto lhes seja distribuido no todo ou em parte". (art. 84) e

IV - essa disposição também é aplicável, segundo os têrmos do parágrafo único do artigo 84, - " à arrecadação dos impostos de competência dos estados, cujo produto êstes venham a distribuir, no todo ou em parte, aos respectivos municípios».

Afora êsses dispositivos genéricos, há as normas distributivas específicas, consoante a sistemática da lei, que focalizaremos de forma sumária, no item subseqüente.

Por exemplo: os impostos sôbre a propriedade territorial rural e sôbre a renda, cabíveis à União, serão distribuídos aos Estados, Distrito Federal e aos Municipios, pelo modo seguinte:

I - o produto do impôsto sôbre a propriedade territorial rural, - "aos municípios da localização dos imóveis», (Artigo 85, I), e

II - o produto da arrecadação na fonte do impôsto incidente sôbre a renda das obrigações da divida pública estadual, municipal e do Distrito Federal, e sôbre os proventos dos seus servidores e dos de suas autarquias, - "aos Estados, ao Distrito Federal e aos Municipios". (Art. 85, II).

III — os Fundos de Participação dos Estados e Municipios, de constituição prevista na E. C. 18, art. 21 , na ordem de $10 \%$ (dez por cento) para cada uma das pessoas jurídicas citadas, sôbre o produto da arrecadação dos impostos federais de renda e de produtos industrializados (consumo), a Lei n. ${ }^{\circ} 5.172$, de 1966, regulou a distribuição pela forma enunciada nos artigos 88 e 91 , a saber:

\section{a) aos Estados e ao Distrito Federal:}

$1-5 \%$ (cinco por cento) em proporção à superfície da entidade beneficiada, $\mathrm{e}$

$2-95 \%$ (noventa e cinco por cento), «proporcionalmente ao coeficiente individual de participação, que resulta da multiplicação do fator população pelo fator inverso da renda "per capita" da entidade partilhante».

b) aos Municipios:

19) O procedimento distributivo do Fundo de Participação dos Municipios adota um critério peculiar, diferente do que seguiu para a entrega aos Estados. Assim entendido, observa-se que será atribuído «a cada Municipio um coeficiente individual de participação», (art. 91) que se obtém utilizando duas variáveis: escala de população (faixa de número de habitantes) e a de coeficientes ou multiplicadores, que vão de 0,2 (dois décimos) a 4,0 (quatro inteiros). 
$\left.2 .^{\circ}\right)$ Para efetivo pagamento das cotas aos Estados e Municípios, a Lei $n .^{\circ}$ 5.172-66 prescreveu as seguintes regras:

"Art. 92. Até o último dia útil de cada exercício, o Tribunal de Contas da União comunicará ao Banco do Brasil S. A. os coeficientes individuais de participação de cada Estado e do Distrito Federal, calculados na forma do disposto no artigo 88, e de cada Municipio, calculados na forma do disposto no artigo 91 , que prevalecerão para todo o exercício subseqüente.

Art. 93. Até o último dia de cada mês; o, Banco do Brasil S. A. creditará a cada Estado, ao Distrito Federal e a cada Municipio as cotas a êles devidas, em parcelas distintas para cada um dos impostos a que se refere o artigo 86, calculadas com base nos totais creditados ao fundo correspondente no mês anterior. $\S 1$ O $\mathrm{O}$ créditos determinados por êste artigo serão efetuados em contas especiais, abertas automàticamente pelo Banco do Brasil S. A. em sua agência na capital de cada Estado, no Distrito Federal e na sede de cada Municipio, ou, em sua falta, na agência mais próxima.

$\S 22^{\circ}$ O cumprimento do disposto neste arfigo será comunicado pelo Banco do Brasil S. A. ao Tribunal de Contas da União, discriminadamente, até o último dia útil do mês subseqüiente".

$\left.3 .^{\circ}\right)$ Todavia, a lei adotou, prudentemente, um sistema de pesos e contrapesos, isto é, de liberalidades e restrições, impondo aos beneficiados:

I - destinação obrigatória de 50\% (cinqüenta por cento) do total recebido da partilha pela União, ao «orçamento de despesas de capital», e

II - comprovação, perante o Tribunal de Contas da União, do exato cumprimento do disposto no item I, supra.

IV - Partilha do impôsto sôbre combustiveis, lubrificantes, energia elétrica e minerais do País. A Lei n. ${ }^{\circ}$ 5.172, de 1966, reproduz, textualmente, em seu artigo 95 e parágrafo único, as disposições do artigo 23 e seu parágrafo único da Emenda Cons titucional n..$^{\circ} 18$, de 1965. Assim é que do "quantum" arrecadado serão entregues aos Estados, ao Distrito Federal e aos Municipios, o correspondente aos percentuais abaixo:

$60 \%$ - do impôsto sôbre operações relativas a combustiveis, lubrificantes e energia elétrica, e $90 \%$ - do que incidir sôbre operações relativas a minerais do Pais. 


\section{V - AS NORMAS GERAIS DE DIREITO TRIBUTARIO}

O Livro Segundo da Lei . $^{\circ} 5.172$, de 1966 , que é um repositório de normas genéricas de direito tributário, abrange na sistemática estrutural 4 títulos, o primeiro destinado à "Legislação Tributária»; o segundo, à «Obrigação Tributária»; o terceiro, ao «Crédito Tributário» e o último à «Administração Tributária».

A parte da. "Legislação Tributária" cuida, em sintese, das fontes autênticas da carga fiscal ou imposição tributária e sua majoração, com prevalência absoluta da lei, - expressão primacial do direito escrito ou positivo.

Todavia, os tratados e as convenções internacionais têm poder revogatório ou modificador da «legislação tributária interna e serão observados pela que lhes sobrevenha». (Art. 98).

Para os decretos resultantes do Poder Regulamentar do Executivo, foram marcadas as lindas de sua conformidade às "leis em função das quais sejam expedidos». (Art. 99).

Igualmente, são versadas as categorias normativas secundárias sob a designação de - "normas complementares das leis, dos tratados e das convenções internacionais e dos decretos,» arrolados nos incisos do artigo 100, como sejam:

a) os atos normativos de procedência administrativa;

b) as decisões de órgãos singulares ou coletivos de jurisdição administrativa;

c) as práticas consuetudinárias seguidas pela administração, e

d) os acôrdos celebrados entre a União, os Estados. o Distrito Federal e os Municipios.

Cura a lei, também, da "quaestio juris" da vigência, da aplicação, interpretação e integração da legislação tributária, assentando principios e regras de orientação casuística, inerente à fenomenologia da vida do direito.

A tônica orientacional é a data da publicação, para início de vigência, salvante disposição expressa, nos atos administrativos e nas decisões de efeitos normativos, enquanto os convênios vigem na data nêles previstas. Entretanto, as leis tributárias que gravarem o patrimônio e a renda, seja pela majoração de impostos, seja pela criação de novas incidências fiscais, e à̀s que extinguirem ou reduzirem isenções - «Entram em vigor no primeiro dia do exercício seguinte àquele em que ocorra a sua publicação». (Art. 104).

$\mathrm{Na}$ aplicação da lei tributária, há que levar em consideração as duas capitais situações. A primeira é a que diz respeito à aplicação imediata "aos fatos geradores futuros e aos pendentes" (artigo 
105). Na aplicação respeitante a ato ou fato passado, cumpre observar as seguintes limitações:

"Art. 106. A lei aplica-se a ato ou fato pretérito:

I - em qualquer caso, quando seja expressamente interpretativa, excluida a aplicação de penalidade à infração dos dispositivos interpretados;

II - tratando-se de ato não definitivamente julgado:

a) quando deixe de defini-lo como infração;

b) quando deixe de tratá-lo como contrário a qualquer exigência de ação ou emissão, desde que não tenha sido fraudulento e não tenha implicado em falta de pagamento de tributo;

c) quando lhe comine penalidade menos severa que a prevista na lei vigente ao tempo da sua prática".

O Capítulo IV - "Interpretação e integração da legislação tributária." - é de suma importância para o exato conhecimento e aplicação do direito impositivo ao "hecho imponible», alfa e ômega de todos os desentendimentos entre o «erarium» e o contribuinte.

Não poderia deixar, pois, um trabalho organizado com viso à codificação, ou seja, à reunião rum só corpo jurídico de todo o sistema tributário, de fundo nacional, de conter regras interpretativas especificas aplicáveis ao processo cognitivo da legislação tributária, mormente quando se o deve a um Rubens Gomes de Souza, mestre que já havia prestado relevante serviço à cultura especializada do Direito Financeiro pátrio, còm a tradução ao vernáculo da obra de Ezio Vanoni - "Natura ed interpretazione delle Leggi Tributarie».

O ordenamento cognoscitivo ora abordado está compreendido nas regras dos artigos 107 a 112 , rezando o primeiro que - "A legislação tributária será interpretada conforme o disposto neste capitulo".

A lei de introdução ao Código Civil Brasileiro (Decreto-lei n..$^{4} 657$, de 4-10-1942), em seu artigo $4 .^{\circ}$ autoriza ao juiz, nos casos de lacuna ou omissão da lei, decidir "de acôrdo com a analogia, os costumes e os princípios gerais de direito». Agora, o artigo 108 da Lei n. 5.172 , de 1966, dispõe que: - "Na ausência de disposição expressa", o aplicador fará uso, "na ordem indicada", dos seguintes processos integrativos:

a) a analogia,

b) us princípios gerais de direito tributário,

c) os princípios gerais de direito público, e

d) a eqüidade. 
Perfilhou assim o legislador a moderna orientação perceptual de interpretação, que opugna à tradicional hermenêutica dos praxistas, que não reconhecia ao processo analógico condições de aplicabilidade às leis fiscais, materiais ou substantivas, porque confundiam a analogia com a interpretação extensiva ou ampliativa, que resultava dos casos em que - "Lex minus dixit quam voluit".

Significativo é, a êsse propósito, o ensinamento de Carlos Maximiliano:

"Tratem-se as normas de tal espécie como se foram rigorosamente taxativas; deve, por isso, abster-se o aplicador de lhes restringir ou dilatar o sentido». (Cfr. Hermenêutica etc., pág. 398. O grifo é do original).

E como o assunto cai dentro daquela classificação dos angloamericanos de "matter of opinion», o debate continua, se bem que, a pouco e pouco, a corrente pró-analogia vai, a olhos vistos, ganhando terreno pela adesão de modernos tratadistas. A controvérsia deriva da distinção feita por muitos autores, entre interpretação, que é a atividade cognoscitiva do sentido e alcance da norma jurídica, a integração que visa a suprir a lei no caso de lacuna ou omissão, e aplicação, em sentido estrito, que é a subsunção da regra abstrata ao fato concreto.

É o que esclarece, "mutatis mutandis", Horácio Belsunce, na excelente monografia - "La Interpretación de la Ley Tributária» - (Págs. 8/9) ao aceitar, com Gianini, que, na aplicação da lei, há dois momentos que se denominam interpretação e integração da lei. Contudo, não admite a aplicação analógica em direito tributário substantivo, dada a natureza da lei fiscal e o conteúdo particular das relações que regula». Com efeito, lei de categoria especial ou excepcional, a muitos parece que, sendo imperfeita, necessita convalidar-se através do ato-condição (orçamento), para tornar-se exeqüível.

Também Osvaldo de Moraes, no escorreito opúsculo editado pela "Revista dos Tribunais", sob o titulo - "A Analogia no Direito Tributário Brasileiro», lembrando embora o "princípio da legalidade» como limite à interpretação analógica ou analogia «legis», adverte:

"A tendência irresistivel da integração para não deixar sem solução os casos apresentados produz no direito tributário essa velha dor de cabeça" - tudo isso só pode ser contido se o direito positivo consignar regra proibitiva. Isso não significa a remoção das lacunas; elas continuam a existir, mas não preenchiveis por êsse método integrativo. Dai parece pouco exata a afirmação de que a norma tributária não tem lacuna». (Pág. 59). 
Também o professor Ezio Vanoni (Cfr. op. cit., pág. 325), assim formula o seu autorizado depoimento sôbre a controvérsia:

"O emprêgo da analogia na interpretação das leis tributárias tem sido, e ainda é, fortemente combatido na doutrina e na jurisprudência. É especialmente contraditória a prática fiscal, em que geralmente se afirma o principio da inadmissibilidade da aplicação analógica das leis tributárias, muito embora em seguida seja necessário recorrer, de maneira mais ou menos declarada, ao emprêgo daquele processo de interpretação para preencher a evidente insuficiência da lei".

O processo integrativo para o preenchimento da lacuna ou omissão da lei, denominado "analogia legis", pressupõe a disposição da lei, da norma juridica para ser aplicada a uma hipótese ou a um caso concreto semelhante ou análogo ao previsto no texto legal, enquanto a outra espécie, a analogia "iuris", como ensina Carlos Maximiliano, (ob. cit., pág. 258) "lança mão do conjunto de normas disciplinadoras de um instituto que tenha pontos fundamentais de contacto com aquêle que os textos positivos deixaram de contemplar; a primeira, encontra reservas de soluções nos próprios repositórios de preceitos legais; a segunda, nos principios getais de Direito". (Grifado no original) .

O recurso aos principios gerais de Direito, emanações da consciência juridica universal, histórica e socialmente estratificada, pelo aplicador da lei, quando omissa, está autorizado pela regra "in fine" do artigo $4 .^{\circ}$ da nova Lei de Introdução ao Código Civịl Brasileiro.

No caso vertente da Lei $n .^{\circ} 5.172$, de 1966, o escolasta depara-se com a referência expressa aos principios gerais de direito tributário, "prima facie" e, subseqüentemente, o campo mais extenso do direito público (Constitucional, Administrativo, Financeiro, Processual, Internacional, etc.).

Fechando a enumeração do artigo 108, vem a eqüidade ou "Equity" dos anglo-americanos como meio final a ser utilizado pelo aplicador da lei. A "aequitas" é um conceito ético filosófico, de justiça, como norma de vida social, pois já Celso definia o direito como sendo a - «ars bonit et aequi», completada, mais tarde, por Ulpiano, com as famosas máximas: «honeste vivere, al terum non laedere, sui cuique tribuere».

Na conceituação processualistica de Paula Batista, a eqüidade, em direito judiciário, é a que leva os magistrados, - "no silêncio, dúvida ou obscuridade das leis escritas, a submeterem-se por um modo esclarecido à vontade suprema da lei, para não cometerem em nome dela injustiças que não desonram senão os seus executores". (Apud. Carlos Maximiliano, op. cit., pág. 212). 
A lei menciona, ao cabo, os "princípios gerais de direito privado", no caso aludindo ao Código Civil Brasileiro, que é o direito privado «par excellence» inclusive, é claro, às disposições da "Lei de Introdução", com as suas famosas regras interpretativas e de direito intertemporal ou de extraterritorialidade, no campo do direito internacional, ou direito das gentes.

Restringe, porém, o uso à atividade prospectiva ou investigatória, pertinente ao conceptualismo e formalismo dos institutos juridicos e financeiros, eis que é reservado à lei fiscal a prerrogativa definidora dos efeitos tributários, como segue:

"Art. 109. Os principios gerais de direito privado utilizam-se, para pesquisa da definição, do conteúdo e do alcance de seus institutos, conceitos e formas, mas não para definição dos respectivos efeitos tributários".

Sàbiamente, pois, o legislador opôs limites ao trabalho de exegese do aplicador da «legislação tributária», seja de ordem interpretativa, seja de integração. Em primeiro lugar, advém o "princípio da legalidade", fulcro da carga tributária, já esposado pelos antigos, haja vista o brocardo latino - "Nullum censu sine lege", e estabelecido de modo taxativo no parágrafo primeiro do artigo 106 , "verbatim":

"O emprêgo da analogia não poderá resultar na exigência de tributo não previsto em lei".

Em segundo, vem a estipulação de que, para os casos de legislação tributária excepcional, cabe a interpretação literal, gramatical ou filológica, pela forma prescrita no artigo 111, "verbis":

Interpreta-se literalmente a legislação tributária que disponha sôbre:

I - suspensão ou exclusão do crédito tributário;

II - outorga de isenção, e

III - dispensa do cumprimento de obrigações tributárias acessórias.

Ainda, o recurso aos processos e meios que visam ao conhecimento do "sentido e do alcance das expressões do Direito" encontra reservas na própria lei, "vergi gratia":

a) da integração analógica não pode surgir carga tributária não declarada em lei (art. $\left.108, \S 10^{\circ}\right)$, e

b) da aplicação da eqüidade "não poderá resultar dispensa do pagamento de tributo devido $\left(\S 2 .^{\circ}\right.$ do artigo 108). 
Depois, quando dúvida surgir na inteligência do texto legal, é de aceitar-se o "in dubio contra fiscum", utilizando-se a interpretação que favoreça ao contribuinte, já revelada na parêmia "faworasilia amplianda, odiosa restringenda", ou, nos exatos têrmos da lei:

"Art. 112. A lei tributária que define infrações, ou lhes comina penalidades, interpreta-se da maneira mais favorável ao acusado, em caso de dúvida quanto:

I - à capitulação legal do fato;

II - à natureza ou às circunstâncias materiais do fato, ou à natureza ou extensão dos seus efeitos;

III - à autoria, imputabilidade, ou punibilidade;

IV - à natureza da penalidade aplicável, ou à sua graduação".

O Título II contém as normas disciplinadoras da "Obrigação Tributária", a conceituação desta e dos elementos da relação jurídica de ordem tributária: a lei, o fato gerador, o sujeito ativo (o Estado), o sujeito passivo (o contribuinte "de facto"), e o objeto ou prestação pecuniária definida em lei. Rege, ainda, a capacidade tributária do contribuinte, o domicílio tributário e a responsabilidade pelo pagamento do tributo, que se estende a sucesśores e a terceiros e, por fim, a responsabilidade por infrações.

Comentando o projeto do Código Tributário elaborado pelo jurista Rubens Gomes de Souza e que, com poucas alterações, foi convertido na Lei n. ${ }^{\circ} 5.172$, de 1966 , assim se pronuncia Osvaldo de Moraes (op. cit., pág. 79):

"Finalmente, ponto importante resolveu o Projeto: a extensão do principio de legalidade. A elaboração a êsse respeito tinha sido escassa e o Projeto no artigo 52, parágrafo único, fixou tal extensão. Assim, êle abrange a definição do fato gerador da obrigação principal, o montante da alíquota do tributo, a base do seu cálculo, o respectivo contribuinte, a definição de infrações, as respectivas penalidades, a concessão de isenção, anistia ou moratória, a autorização de remissão de créditos tributários e a disciplina da transação a seu respeito" (art. 52, parágrafo único e incisos I a IV).

A obrigação tributária é definida (art. 113) como principal ou substancial e acessória ou adjeta, podendo esta converter-se em principal, pela inobservância, "relativamente à penalidade pecuniária" $\left(\S 3 .^{\circ}\right)$. Principal é a obrigação que resulta do fato gerador e "tem por objeto o pagamento de tributo ou penalidade pecuniária" $\left(\S 1 .^{\circ}\right)$, enquanto a acessória - "decorre da legislação tributária 
e tem por objeto as prestações, positivas ou negativas, nela previstas no interêsse da arrecadação ou da fiscalização dos tributos" $\left(\S 2 .^{\circ}\right)$.

Quanto ao fato gerador, que é, no dizer do autor do projeto de lei - " a hipótese prevista na lei tributária em abstrato, isto é, em têrmos gerais e objetivamente, como dando origem à obrigação de pagar o tributo" (Cfr. Compêndio de Legislação Tributária, pág. 67), a lei prevê duas modalidades. A primeira, que se liga à obrigação principal, é conceituada (art. 114) como "a situação definida em lei como necessária e suficiente à sua ocorrência». A segunda, relativa à «obrigação acessória, é qualquer situação que, na forma da legislação aplicável, impõe a prática ou abstenção de ato que não configure obrigação principal". (artigo 115).

O crédito tributário, matéria do Título III - "decorre da obrigação principal e tem a mesma natureza desta" (art. 139), e constitui-se do lançamento (art. 142) nos casos que a lei assim o determine (art. 149), e que pode resultar da declaração do sujeito passivo (art. 147) ou arbitramento em processo fiscal (art. 148) ou, ainda, em "lançamento por homologação" (artigo 150).

Situações há, contudo, que suspendem a exigibilidade do crédito tributário (art. 151), pela cobertura que lhes dá a ordem juridica, como a moratória (geral ou individual); o depósito integral da obrigação; os efeitos suspensivos das reclamações e recursos na ordem administrativa, e a medida liminar concedida em mandado de segurança.

Já a extinção do crédito tributário decorre ou do pagamento ou de outras modalidades extintivas, conforme a enumeração do artigo 156, ccmo sejam: - " a compensação, a transação, a remissão, a prescrição e a decadência, a conversão de depósito em renda, a decisão ad’ministrativa irreformável, a "res judicata", etc.

Nos casos de recolhimento indevido de tributos, a lei assegura a pronta restituição do indébito acrescido das penas acessórias (art. 167), vencendo juros simples - "a partir do trânsito em julgado da decisão definitiva que a determinar" (art. 167, § $1 .^{\circ}$ ).

Estabelece mais, a lei, outras modalidades de extinção do crédito tributário, pela remissão total ou parcial da divida, mediante despacho fundamentado da autoridade competente (artigo 172); a transação, através de concessões mútuas (art. 171) e bem assim o instituto da prescrica qu qüinqüenária na esfera administrativa, pró (art. 168) ou contra (arts. 173/174) o sujeito passivo, e ainda a de dois anos, para o contribuinte promover a ação anulatória de decisão administrativa (art. 169).

A sistemática da Lei n. ${ }^{\circ} 5.172$, de 1966 , consigna, como é o caso do art. 175 , causas excludentes do crédito tributário, como 
a isenção que, segundo o preceito do art. 176 - "ainda quando prevista em contrato, é sempre decorrente de lei que especifique as condições e requisitos exigidos para a sua concessão, os tributos a que se aplica e, sendo o caso, o prazo de sua duração".

A outra excludente é a anistia, geral ou limitada, e que, de acôrdo com o art. 180 - "abrange exclusivamente as infrações cometidas anteriormente à vigência da lei que a concede". Quando não fôr geral, há de ser casuística, mediante - "despacho da autoridade administrativa", em requerimento do interessado, pela forma estabelecida no art. 182 .

O Capitulo VI regula as garantias e privilégios conferidos ao crédito tributário, além de outros, constantes em lei. Por exemplo, declara-se no artigo 184 que:

“Sem prejuizo dos privilégios especiais sôbre determinados bens, que sejam previstos em lei, responde pelo pagamento do crédito tributário a totalidade dos bens e das rendas, de qualquer natureza, do sujeito passivo, seu espólio ou sua massa falida, inclusive os gravados por ônus real ou cláusula de inalienabilidade ou impenhorabilidade, seja qual fôr a data da constituição do ônus ou da cláusula, excetuados ùnicamente os bens e rendas que a lei declare absolutamente impenhoráveis».

Crédito privilegiado, o crédito tributário, segundo declara o art. 186 - " prefere a qualquer outro, seja qual fôr a natureza ou o tempo da constituição dêste, ressalvados os créditos decorrentes da legislação do trabalho".

O Título IV, final, compreendendo matéria concernente à administração tributária, regula a fiscalização do cumprimento das regras fiscais, pelas pessoas físicas ou naturais e jurídicas, podendo a autoridade recorrer, subsidiàriamente, a órgãos, entidades e estabelecimentos, que menciona no art. 197, "verbis":

"Mediante intimação escrita, são obrigados a prestar à autoridade administrativa tôdas as informações de que disponham com relação aos bens, negócios ou atividades de terceiros: de ofício;

I - os tabeliães, escrivães e demais serventuários

II - os bancos, casas bancárias, caixas econômicas e demais instituições financeiras;

III - as emprêsas de administração de bens;

IV - os corretores, leiloeiros e despachantes oficiais;

$\mathrm{V}$ - os inventariantes;

VI - os sindicos, comissários e liquidatários; 
VII - quaisquer outras entidades ou pessoas que a lei designe, em razão de seu cargo, ofício, função, ministério, atividade ou profissão".

Versa e define, outrossim, a Divida Ativa Tributária, que é - " proveniente de crédito dessa natureza, regularmente inscrita na repartição administrativa competente, depois de esgotado o prazo fixado para pagamento pela lei ou por decisão final proferida em processo regular" (art. 201).

Regula, ainda, o fornecimento das certidões negativas de débitos tributários, pelas repartições arrecadadoras, mediante requerimento do contribuinte, na forma do artigo 205, ressonância, aliás, do mandamento constitucional de 1946 (art. 141, § 36, III).

Finalizando o disciplinamento fiscal-administrativo, a Lei n. 5.172, em suas «Disposições Finais e Transitórias», define a expressão genérica "Fazenda Pública" (art. 209); a contagem dos prazos (art. 210), a assistência técnica a cargo do Conselho Técnico de Economia e Finanças, do Ministério da Fazenda (artigo $211)$; consolidação anual, por decreto, em texto único, da legislação de cada tributo (art. 212); convênios para estabelecimento de aliquota uniforme entre estados de uma mesma região geo-econômica (art. 213), extensivos aos municípios de um mesmo estado (parágrafo único); convênios relativos à incidência ou exclusão de mercadorias nos casos do impôsto de circulação de mercadorias (art. 210) e outras disposições (art. 215 e 216) e, por derradeiro, a vigência da lei a partir de $10^{\circ}$ de janeiro de 1967 , em todo o território nacional esgotada a "vacatio legis" (art. 217), revogadas as disposições com ela não condizentes.

\section{VI - CONSIDERAÇ.̋ES FINAIS}

Chega, pois, ao término, a sintese interpretativa do nôvo sistema tributário nacional, que substituiu, integralmente, a discriminação de rendas da Constituição Federal de 1946.

Criticado pelo pan-economismo da linha direcional do sistema, de repercussões imprevisiveis na fluência normal da atividade financeira do Pais, a estrutura fiscal recém-institucionalizada ainda não logrou ingressar no consenso geral dos contribuintes, e daí as alterações que se têm verificado e que ainda ocorrerão, até a piena estabilidade do sistema.

Dentre as alterações "post lege" N. 5.172 , de 1966, citam-se, dentre as mais importantes:

1) Decreto-lei n. ${ }^{\circ} 27$, de 14-11-1966, que acrescentou à precitada lei o artigo 218, estendendo o "princípio da legalidade" à cobrança de contribuições típicas, "exempli gratia": a) sindical (antigo "impôsto sindical"); b) quotas de previdência; c) taxas 
para constituir o «Fundo de Assistência e Previdência do Trabalhador Rural»; d) a destinada ao «Fundo de Garantia do Tempo de Serviço", e outras de fins sociais;

2) Decreto-lei n. ${ }^{\circ} 28$, de 14-11-1966,que autoriza ao Govêrno da União a regulamentar a cobrança do impôsto estadual sôbre a circulação de mercadorias, notadamente ao que diz respeito à aliquota: limite, reajustamento da cotidade e outras providências.

3) Constituição Federal promulgada em 24-1 1967, que estabeleceu a garantia constitucional do parágrafo 34 do artigo 141 , do Estatuto Político de 1946, com pequena modificação redacional, porém não de fundo, reproduzido no parágrafo 29 do artigo 150 , erguendo, assim, obstáculos ao arbítrio da legiferação tributária:

"Nenhum tributo será exigido ou aumentado sem que a lei o estabeleça: nenhum será cobrado em cada exercício sem prévia autorização orçamentária, ressalvados a tarifa adtuaneira e o impôsto lançado por motivo de guerra".

4) Encerrando a série, vem o nupérrimo Ato Complementar n. ${ }^{\circ} 34$, de 31-1-1967, introduzindo alterações na Lei n. ${ }^{\circ} 5.172$, de 1966, na parte que disciplina o regime juridico das "isenções, reduções e outros favores fiscais", concedidos pelos Estados e Municípios, alusivos ao já famigerado impôsto sôbre circulação de mercadorias, de competência arrecadadora pelos Estados e Municípios.

Para finalizar o escólio da Lei n. ${ }^{\circ} 5.172$, de 1966 , mister é que se não clvide o anteprojeto de lei orgânica do Processo Tributário, a cargo do jurista Ulhoa Canto, volume n. ${ }^{\circ} 2$ da série "Comissão de Reforma do Ministério da Fazenda", editado pela Fundação Getúlio Vargas, 1964.

Repositório das normas regedoras do processo tributário, seja de natureza administrativa seja judicial ou litigiosa, o referido esbŝço de lei elaborado pelo citado jurista, disciplinando matéria de direito formal ou adjetivo, vem a ser, assim, o complemento natural do direito material ou substantivo de natureza tributária. 